\title{
Synthesis and Characterization of Enaminone Derivatives of Barbituric Acid
}

\section{Erkan FIRINCI ${ }^{1 *}$}

\begin{abstract}
In this study, four enaminones derived from barbituric acid were synthesized with the reaction of 5-formylbarbituric acid and selected primer amines with high yield. The structures of all compounds were proved by using ATR-FTIR, ${ }^{1} \mathrm{H}$ and ${ }^{13} \mathrm{C}$ NMR spectroscopy. Also, ${ }^{19} \mathrm{~F}$ NMR spectroscopy was used for characterization of $\mathbf{2 d}$. The obtained spectroscopic results have complied with reported similar derivatives in literature.
\end{abstract}

Keywords: Barbituric acid, Enaminone, Condensation reaction, Spectroscopy

\section{Barbitürik Asitin Enaminon Türevlerinin Sentezi ve Karakterizasyonu}

ÖZET: Bu çalışmada barbitürik asitten türeyen dört enaminon türevi 5-formilbarbitürik asit ve seçilen birincil aminlerin reaksiyonu ile yüksek verimle sentezlenmiştir. Sentezlenen bütün bileşiklerin yapıları ATR-FTIR, ${ }^{1} \mathrm{H}$ ve ${ }^{13} \mathrm{C}$ NMR spektroskopileri kullanılarak kanıtlanmıştır. Bileşik 2d'nin yapısal karakterizasyonun da ayrıca ${ }^{19} \mathrm{~F}$ NMR spektroskopisi kullanılmıştır. Elde edilen spektroskopik sonuçlar literatürdeki rapor edilmiş benzer türevler ile uyumludur.

Anahtar Kelimeler: Barbitürik asit, Enaminon, Kondenzasyon reaksiyonu, Spektroskopi

\footnotetext{
${ }^{1}$ Erkan FIRINCI (Orcid ID: 0000-0003-0741-9608), Aydın Adnan Menderes University, Faculty of Art and Science, Department of Chemistry, Efeler, Aydın, Turkey

* Sorumlu Yazar/Corresponding Author: Erkan FIRINCI, e-mail: efirinci@adu.edu.tr
} 


\section{INTRODUCTION}

Enaminones are a significant subclass of organic compounds which contain conjugated $\mathrm{N}$ $\mathrm{C}=\mathrm{C}-\mathrm{C}=\mathrm{O}$ fragment owing to fact that they include both nucleophilic and electrophilic moieties at same skeleton (Castro-Alvarez et al., 2017). These active sites help to synthesis of linear or cyclic hetero atom containing organic compounds (Negri et al., 2004; Kumar et al., 2018). Both enaminones and the organic compounds derived from them have biological activity against the most harmful microorganisms (Negri et al., 2004; Baldwin et al., 2018). Therefore, there is still a demand for synthesis of new enaminone derivatives. The most common way for preparation of enaminone derivatives is the condensation of a $\beta$-diketone and a primary amine at mild condition in an organic solvent (Elassar and El-Khair, 2003). Barbituric acid is more convenient candidate for reach enaminones so it contains $\beta$-diketone fragment in the six-membered ring (Mahmudov et al. 2014). Barbituric acid derivatives have been widely used in syntheses of different type complexes because they have three oxygen and two nitrogen atoms which can bind to transition metal center (Firınc1 et. al, 2017). Also, an active methylene group is presented in the skeleton of barbiturates for preparation of organic compounds. On the other hand, the compounds derived from barbituric acid have attracted much interest as many barbiturate derivatives are pharmacologically active (Neumann et al, 2014). In this context, the barbiturate bearing enaminones were synthesized by reaction of 5formylbarbituric acid and selected primer amines in presented study. The structures of the prepared compounds were elucidated by ATRFTIR, ${ }^{1} \mathrm{H}$ and ${ }^{13} \mathrm{C}$ NMR spectroscopy.

\section{MATERIAL AND METHODS}

\section{Materials and Physical Measurements}

All chemical reagents were obtained commercially and used without further purification. 5-formyl barbituric acid was synthesized according to literature (Neumann et al, 2014). Melting points were measured with a Stuart SMP30 melting point apparatus. Infrared spectra were measured on an ATR Spectrum-II, Perkin Elmer spectrometer. Elemental analyses were performed by ODTU Microlab (Ankara, Turkey). ${ }^{1} \mathrm{H},{ }^{13} \mathrm{C}$ and ${ }^{19} \mathrm{~F}$ NMR spectra were measured on a Varian 400 spectrometer and referenced internally to residual protio-solvent $\left({ }^{1} \mathrm{H}\right)$ or solvent $\left({ }^{13} \mathrm{C}\right)$ resonances in $\left(\mathrm{CD}_{3}\right)_{2} \mathrm{~S} .{ }^{19} \mathrm{~F}$ NMR spectra were referenced to $\mathrm{CFCl}_{3}$.

\section{Experimental}

\section{General procedure for synthesis of enaminones (2)}

5-formyl barbituric acid (1, $5.0 \mathrm{mmol})$ and aniline derivative $(5.0 \mathrm{mmol})$ were mixed in 20 $\mathrm{mL}$ of methanol than the mixture was refluxed for $4 \mathrm{~h}$ in presence of catalytic amount of acetic acid. The suspension was cooled down at room temperature and the precipitate was filtered. The solid product was washed with diethyl ether and dried (Figure 1).

\section{Synthesis of 2a}

Pale orange powder, $0.52 \mathrm{~g}$, Yield: $53.2 \%$, m.p.: $262-264{ }^{\circ} \mathrm{C}$ (decom.), IR $\left(v \mathrm{~cm}^{-1}\right)$ : 3245 , 3174, 3082, 3005, 2825, 1721, 1640, 1633, 1609. Anal. Calc. for $\mathrm{C}_{8} \mathrm{H}_{9} \mathrm{~N}_{3} \mathrm{O}_{3}$ : C, 49.23; $\mathrm{H}$, 4.65; N, 21.53; found: C, 49.27; H, 4.58; N, 21.62. ${ }^{1} \mathrm{H}$ NMR (400 MHz, DMSO-d $6, \delta \mathrm{ppm}$ ): $4.10\left(\mathrm{t}, 2 \mathrm{H}, \mathrm{HNCH}_{2} \mathrm{CH}\right), 5.18(\mathrm{~m}, 2 \mathrm{H}$, $\left.\mathrm{CH}_{2} \mathrm{CH}=\mathrm{CH}_{2}\right), 5.93\left(\mathrm{~m}, 1 \mathrm{H}, \mathrm{CH}_{2} \mathrm{CH}=\mathrm{CH}_{2}\right)$, 8.08 (d, $1 \mathrm{H}, \mathrm{NHCH}=\mathrm{C}, j: 14.5 \mathrm{~Hz}), 10.16$ (m, 1 $\mathrm{H}, \mathrm{NHCH}=\mathrm{C}$ ), 10.56 (br. s, $1 \mathrm{H}, \mathrm{O}=\mathrm{CN} H$ ), 10.65 (br. s, $1 \mathrm{H}, \mathrm{O}=\mathrm{CNH}) .{ }^{13} \mathrm{C}$ NMR $(100 \mathrm{MHz}$, DMSO-d $_{6}, \delta$ ppm): $51.2\left(\mathrm{HNCH}_{2} \mathrm{CH}\right), 89.8$ $(\mathrm{NHCH}=C), \quad 117.5 \quad\left(\mathrm{HNCH}_{2} \mathrm{CH}\right), \quad 134.4$ $\left(\mathrm{CH}_{2} \mathrm{CH}=\mathrm{CH}_{2}\right), 150.9(\mathrm{C}=\mathrm{O}), 158.7(\mathrm{NHCH}=\mathrm{C})$, $163.9(C=\mathrm{O}), 165.9(C=\mathrm{O})$. 


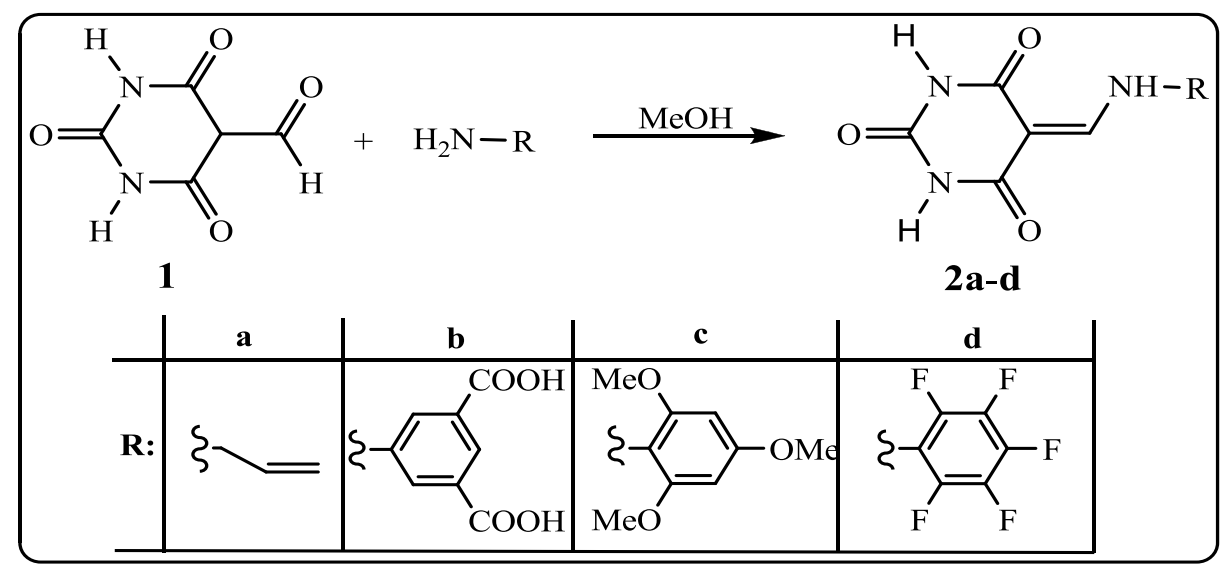

Figure 1. Synthesis of Enaminone Derivatives

\section{Synthesis of $\mathbf{2 b}$}

White powder, $1.59 \mathrm{~g}$, Yield: $99.5 \%$, m.p.: 376-378 ${ }^{\circ} \mathrm{C}$ (decom.), IR ( $\left.v \mathrm{~cm}^{-1}\right)$ : 3528, 3166, 3111, 3003, 2832, 1734, 1724, 1697, 1615. Anal. Calc. for $\mathrm{C}_{13} \mathrm{H}_{9} \mathrm{~N}_{3} \mathrm{O}_{7}: \mathrm{C}, 48.91 ; \mathrm{H}, 2.84 ; \mathrm{N}$, 13.16; found: C, 48.87; $\mathrm{H}, 2.92 ; \mathrm{N}, 13.13 .{ }^{1} \mathrm{H}$ NMR (400 MHz, DMSO-d ${ }_{6}, \delta$ ppm): 8.19 (s, 2 $\left.\mathrm{H}, o-H-\mathrm{C}_{6} \mathrm{H}_{3}\right), 8.27\left(\mathrm{~s}, 1 \mathrm{H}, p-H-\mathrm{C}_{6} \mathrm{H}_{3}\right), 8.54(\mathrm{~d}$, $1 \mathrm{H}, \mathrm{NHCH}=\mathrm{C}, j: 9.4 \mathrm{~Hz}), 10.90(\mathrm{~s}, 1 \mathrm{H}$, $\mathrm{O}=\mathrm{CN} H), 11.03(\mathrm{~s}, 1 \mathrm{H}, \mathrm{O}=\mathrm{CN} H), 11.87(\mathrm{~d}, 1 \mathrm{H}$, $\mathrm{NHCH}=\mathrm{C}, j: 9.4 \mathrm{~Hz}$ ), 13.47 (br. s, 2H, $\mathrm{COOH}$ ). ${ }^{13} \mathrm{C}$ NMR (100 MHz, DMSO-d $\left.6, \delta \mathrm{ppm}\right): 93.4$ $(\mathrm{NHCH}=C), 123.3\left(C_{6} \mathrm{H}_{3}\right), 126.7\left(C_{6} \mathrm{H}_{3}\right), 132.7$ $\left(C_{6} \mathrm{H}_{3}\right), \quad 139.7 \quad\left(C_{6} \mathrm{H}_{3}\right), \quad 150.7 \quad(C=\mathrm{O}), \quad 151.8$ $(\mathrm{NHCH}=\mathrm{C}), 163.6(C=\mathrm{O}), 165.7(C=\mathrm{O}), 166.0$ $(C=\mathrm{O})$.

\section{Synthesis of 2c}

Bright yellow powder, $1.41 \mathrm{~g}$, Yield: 87.9\%, m.p.: $300-302{ }^{\circ} \mathrm{C}$ (decom.), IR $\left(v \mathrm{~cm}^{-1}\right)$ : 3123, 3075, 3040, 2854, 1750, 1716, 1688, 1662. Anal. Calc. for $\mathrm{C}_{14} \mathrm{H}_{15} \mathrm{~N}_{3} \mathrm{O}_{6}: \mathrm{C}, 52.34 ; \mathrm{H}$, 4.71; N, 13.08; found: C, 52.37; H, 4.62; N, 13.12. ${ }^{1} \mathrm{H}$ NMR (400 MHz, DMSO-d $6, \delta$ ppm): $3.63\left(\mathrm{~s}, 3 \mathrm{H}, p-\mathrm{OCH}_{3}-\mathrm{C}_{6} \mathrm{H}_{2}\right), 3.82(\mathrm{~s}, 6 \mathrm{H}, o-$ $\left.\mathrm{OCH}_{3}-\mathrm{C}_{6} \mathrm{H}_{2}\right), 6.86\left(\mathrm{~s}, 2 \mathrm{H}, m-H-\mathrm{C}_{6} \mathrm{H}_{2}\right), 8.58(\mathrm{~d}, 1$ $\mathrm{H}, \mathrm{NHCH}=\mathrm{C}, j: 14.1 \mathrm{~Hz}), 10.84(\mathrm{~s}, 1 \mathrm{H}$, $\mathrm{O}=\mathrm{CN} H), 10.98(\mathrm{~s}, 1 \mathrm{H}, \mathrm{O}=\mathrm{CN} H), 11.88(\mathrm{~d}, 1 \mathrm{H}$, $\mathrm{N} H \mathrm{CH}=\mathrm{C}, j: 14.1 \mathrm{~Hz}) .{ }^{13} \mathrm{C} \mathrm{NMR}(100 \mathrm{MHz}$, DMSO-d 6 , $\delta$ ppm): $56.2\left(\mathrm{OCH}_{3}\right), 60.1\left(\mathrm{OCH}_{3}\right)$, $92.2(\mathrm{NHCH}=C), 96.3\left(C_{6} \mathrm{H}_{2}\right), 134.5\left(C_{6} \mathrm{H}_{2}\right)$, $135.4\left(C_{6} \mathrm{H}_{2}\right), 150.7\left(C_{6} \mathrm{H}_{2}\right), 151.6(C=\mathrm{O}), 153.6$ $(\mathrm{NHCH}=\mathrm{C}), 163.6(C=\mathrm{O}), 166.3(C=\mathrm{O})$.

\section{Synthesis of 2d}

White powder, $0.64 \mathrm{~g}$, Yield: $40.0 \%$, m.p.: 290-292 ${ }^{\circ} \mathrm{C}$ (decom.), IR $\left(v \mathrm{~cm}^{-1}\right)$ : 3258, 3183, 3070, 2810, 1721, 1685, 1640, 1615. Anal. Calc. for $\mathrm{C}_{11} \mathrm{H}_{4} \mathrm{~N}_{3} \mathrm{O}_{3} \mathrm{~F}_{5}$ : C, 41.14; $\mathrm{H}, 1.26 ; \mathrm{N}, 13.08$; found: $\mathrm{C}, 41.17 ; \mathrm{H}, 1.22 ; \mathrm{N}, 13.02 .{ }^{1} \mathrm{H} \mathrm{NMR}$ (400 MHz, DMSO-d 6 , $\delta$ ppm): $8.34(\mathrm{~d}, 1 \mathrm{H}$, $\mathrm{NHCH}=\mathrm{C}, j: 13.3 \mathrm{~Hz}$ ), 10.98 (s, $1 \mathrm{H}, \mathrm{O}=\mathrm{CN} H)$, 11.05 (s, $1 \mathrm{H}, \mathrm{O}=\mathrm{CNH}), 11.46(\mathrm{~d}, 1 \mathrm{H}$, $\mathrm{NHCH}=\mathrm{C}, j: 13.3 \mathrm{~Hz}) .{ }^{13} \mathrm{C} \mathrm{NMR}(100 \mathrm{MHz}$, DMSO-d $_{6}, \delta$ ppm): $94.8(\mathrm{NHCH}=C), 150.5$ $(C=\mathrm{O}), 155.8(\mathrm{NHCH}=\mathrm{C}), 163.1 \quad(C=\mathrm{O}), 166.1$ $(C=\mathrm{O}) .{ }^{19} \mathrm{~F}$ NMR (376 MHz, DMSO-d $\left.6, \delta \mathrm{ppm}\right)$ : $-167.15\left(\mathrm{t}, 2 \mathrm{~F}, m-F-\mathrm{C}_{6} \mathrm{~F}_{5}, J: 52.6\right),-163.06(\mathrm{t}$, $\left.1 \mathrm{~F}, p-F-\mathrm{C}_{6} \mathrm{~F}_{5}, J: 45.1\right),-155,24(\mathrm{~d}, 2 \mathrm{~F}, o-F-$ $\left.\mathrm{C}_{6} \mathrm{~F}_{5}, J: 45.1\right)$.

\section{RESULTS AND DISCUSSION}

The barbiturate enaminone derivatives were synthesized by the condensation of 5formyl barbituric acid and selected primary amine in methanol. The structural characterizations of the compounds were done by ATR-FTIR and NMR spectroscopy.

The IR spectra of $\mathbf{2 a}$, the broad absorption bands for $v(\mathrm{~N}-\mathrm{H})$ of barbiturate amides and enamine appeared at 3250-2825 $\mathrm{cm}^{-1}$. Also, $v(\mathrm{C}$ $\mathrm{H})$ absorption bands of ally moiety overlapped in the same region. The strong sharp bands from 1750 to $1600 \mathrm{~cm}^{-1}$ were attributed to $\mathrm{C}=\mathrm{O}$ stretching vibrations. 


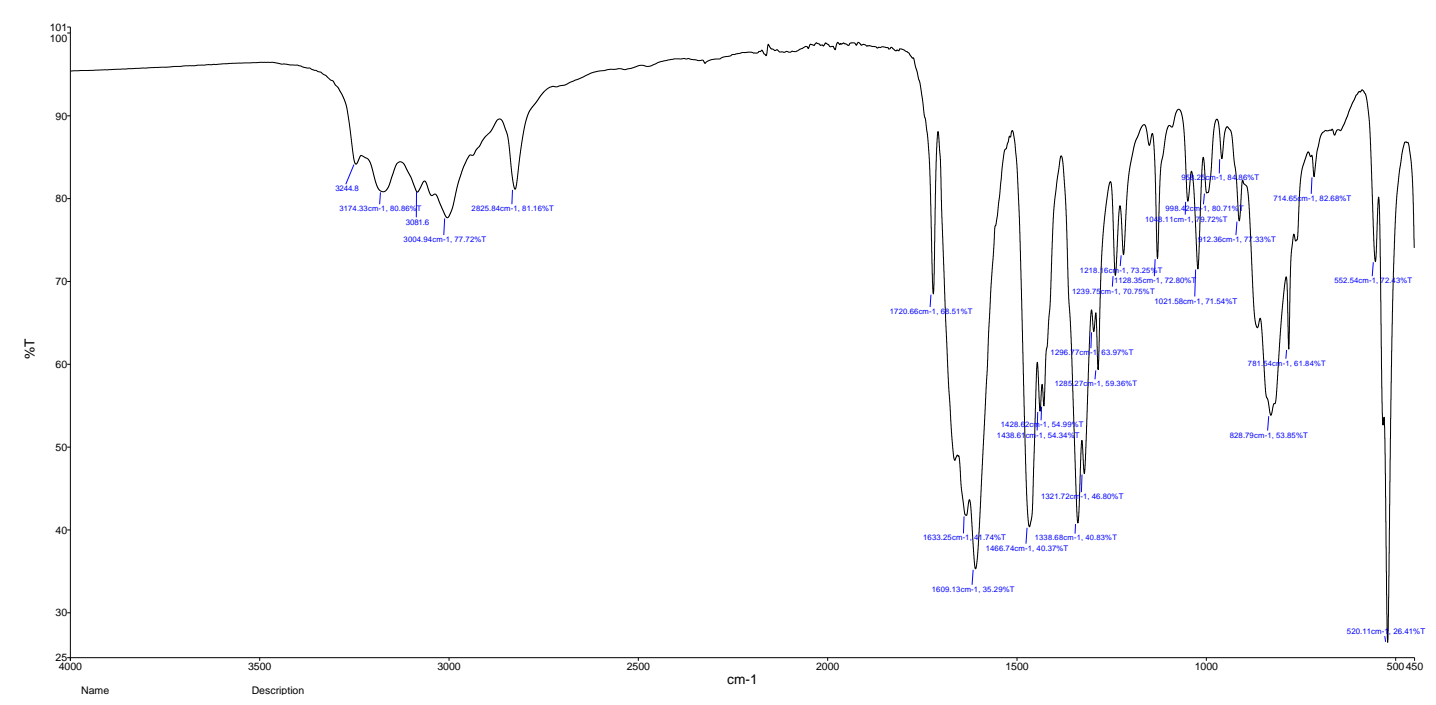

Figure 2. IR spectra of 2a

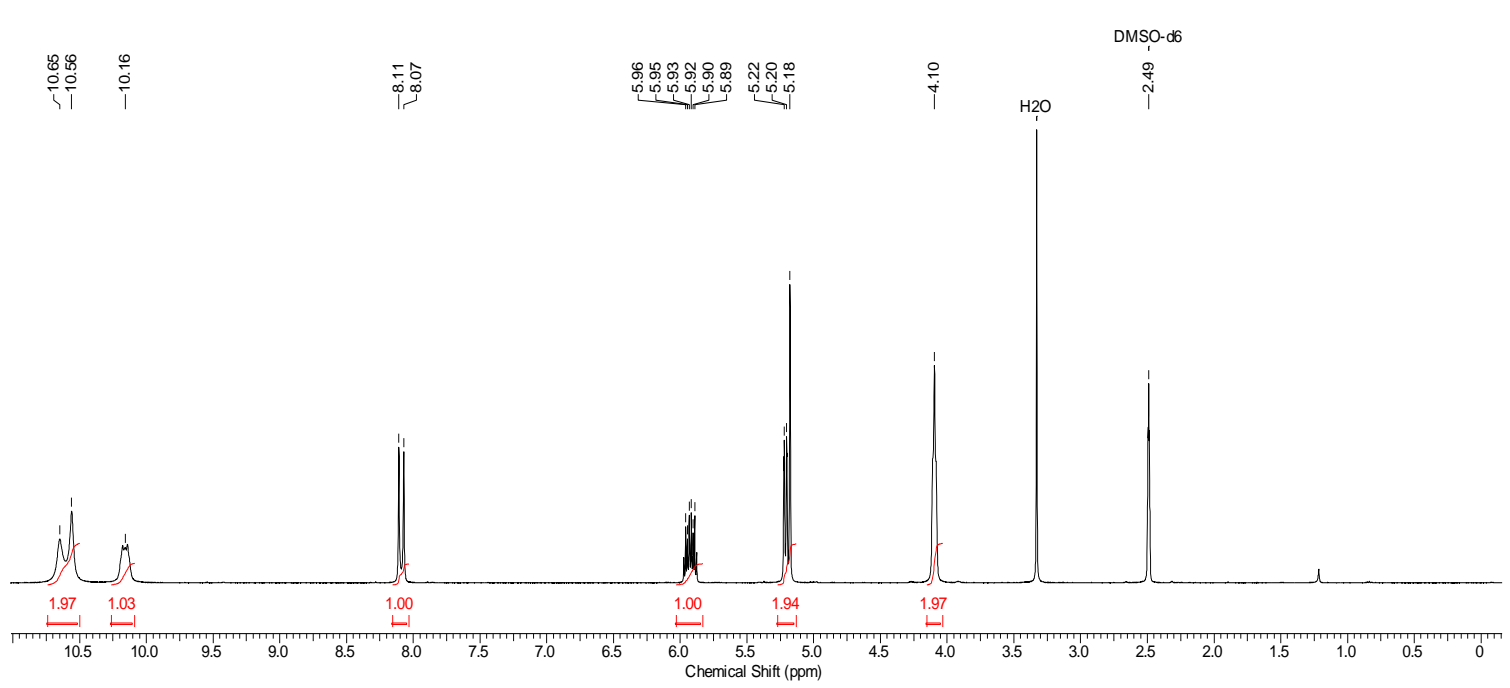

Figure 3. ${ }^{1} \mathrm{H}$ NMR spectra of $\mathbf{2 a}$

The NH proton of enaminone moiety appeared at $10.16 \mathrm{ppm}$ as multiplet in ${ }^{1} \mathrm{H} \mathrm{NMR}$ spectra of 2a. The doublet peak at 8.08 ppm was assigned to $\mathrm{CH}$ proton of enaminone moiety. The barbiturate amide protons gave two broad singlet peaks at 10.56 and $10.65 \mathrm{ppm}$, respectively. The multiplet signals at $4.10,5.18$ and $5.93 \mathrm{ppm}$ belonged to the ally fragment. Also, the found integration areas of protons are compatible with number of protons in $\mathbf{2 a}$.
There are eight carbon atoms in $\mathbf{2 a}$ which have different chemical environment each other and they have been detected by ${ }^{13} \mathrm{C}$ NMR spectroscopy (Figure 4). The ${ }^{13} \mathrm{C}$ NMR spectrum showed that the vinylic carbon atoms of $\mathrm{C}=\mathrm{CH}$ $\mathrm{NH}-\mathrm{CH}_{2}$ gave two peaks at 89.8 and $158.7 \mathrm{ppm}$. The chemical shift of the carbonyl carbons of $\mathbf{2 a}$ were observed at 150.9, 163.9 and $165.9 \mathrm{ppm}$ in the ${ }^{13} \mathrm{C}$ NMR spectra. 


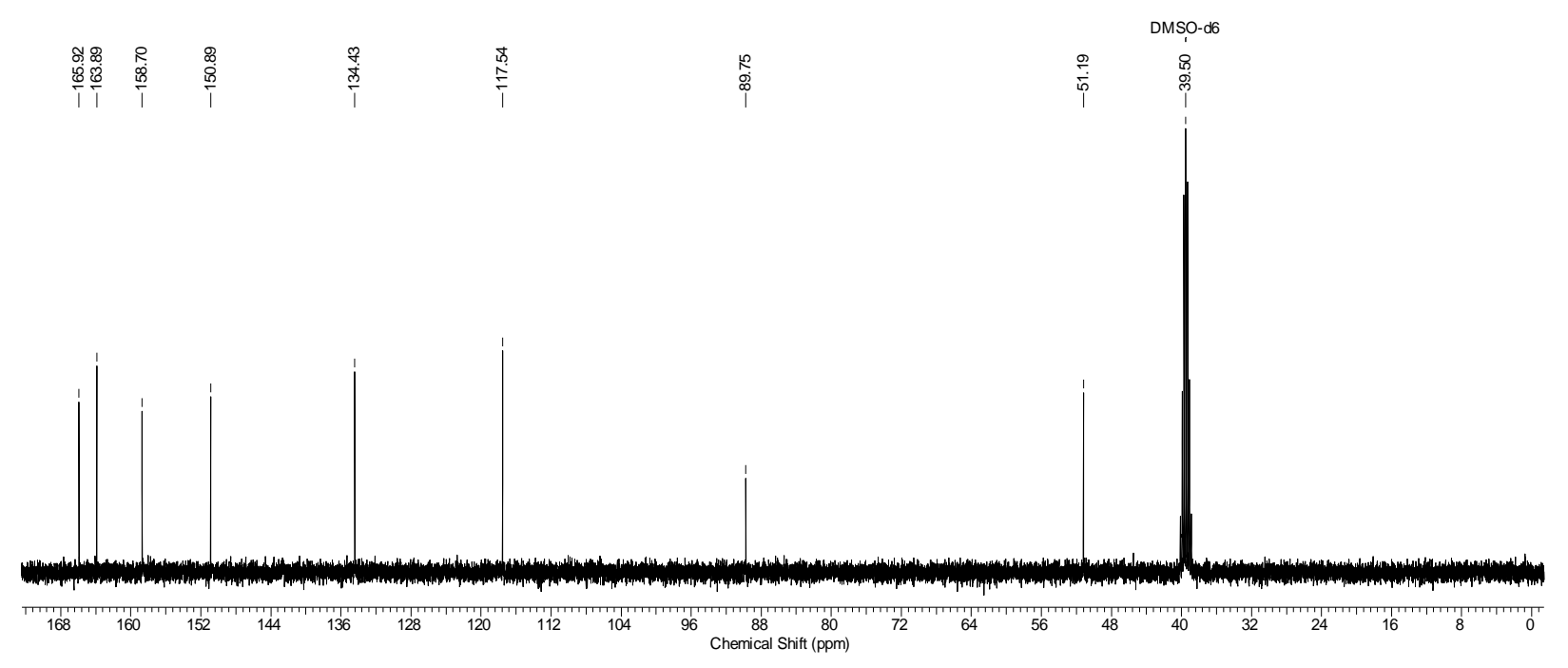

Figure 4. ${ }^{13} \mathrm{C}$ NMR spectra of $\mathbf{2 a}$

For $\mathbf{2 b}$, the broad medium band at 3528 $\mathrm{cm}^{-1}$ was assigned to the stretching vibrations of $v(\mathrm{O}-\mathrm{H})$ from carboxylic acids. The strong peaks around at $3200-2850 \mathrm{~cm}^{-1}$ belonged to $v(\mathrm{~N}-\mathrm{H})$ and $v(\mathrm{C}-\mathrm{H})$ vibrations. The characteristic sharp bands of $\mathrm{C}=\mathrm{O}$ stretching vibrations were observed from 1740 to $1600 \mathrm{~cm}^{-1}$ (Figure 5).

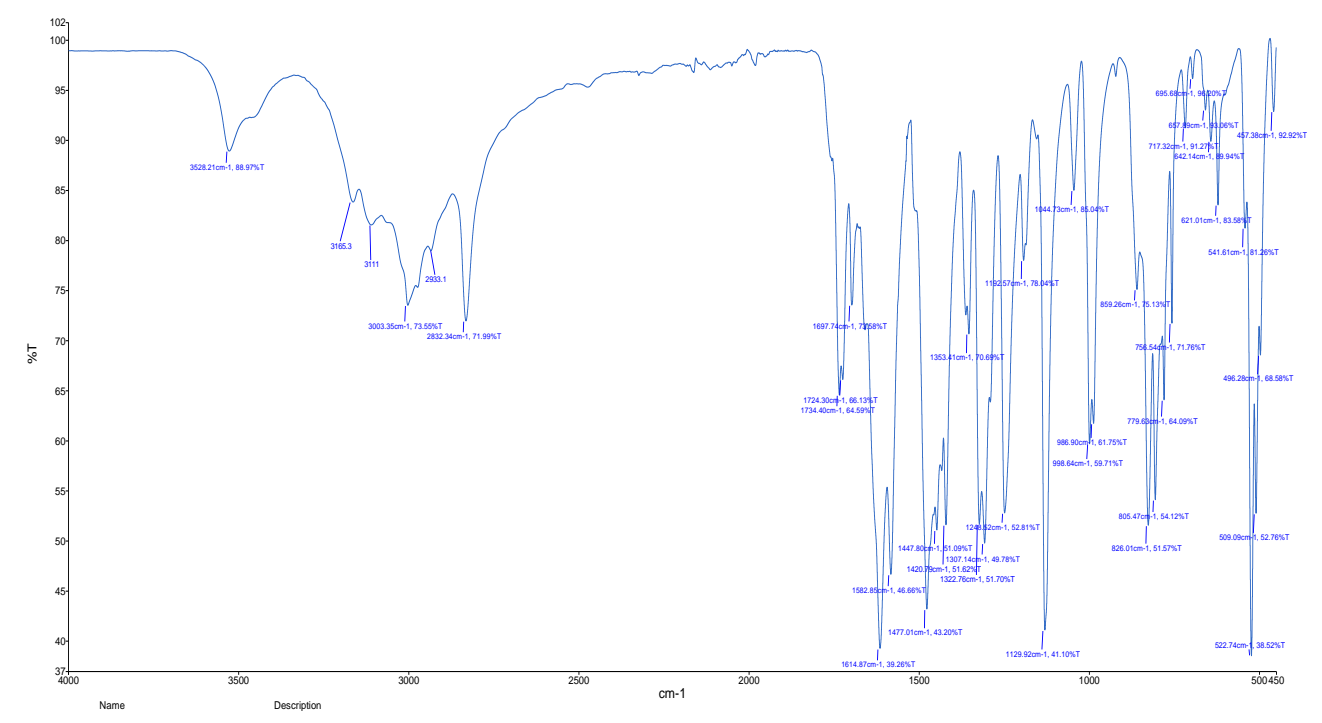

Figure 5. IR spectra of 2b

The broad singlet peak at $13.47 \mathrm{ppm}$ was assigned to $\mathrm{COOH}$ protons of $\mathbf{2 b}$ in the ${ }^{1} \mathrm{H}$ NMR spectra. The $\mathrm{CH}$ and $\mathrm{NH}$ protons of enaminone moiety gave douplet at 8.54 and $11.87 \mathrm{ppm}$, respectively. The $\mathrm{NH}$ protons of barbiturate ring appeared at 10.90 and $11.03 \mathrm{ppm}$ as singlet. Two singlets at 8.19 and $8.27 \mathrm{ppm}$ belonged ortho and para protons of aromatic ring respectively according to the integration areas of peaks. 


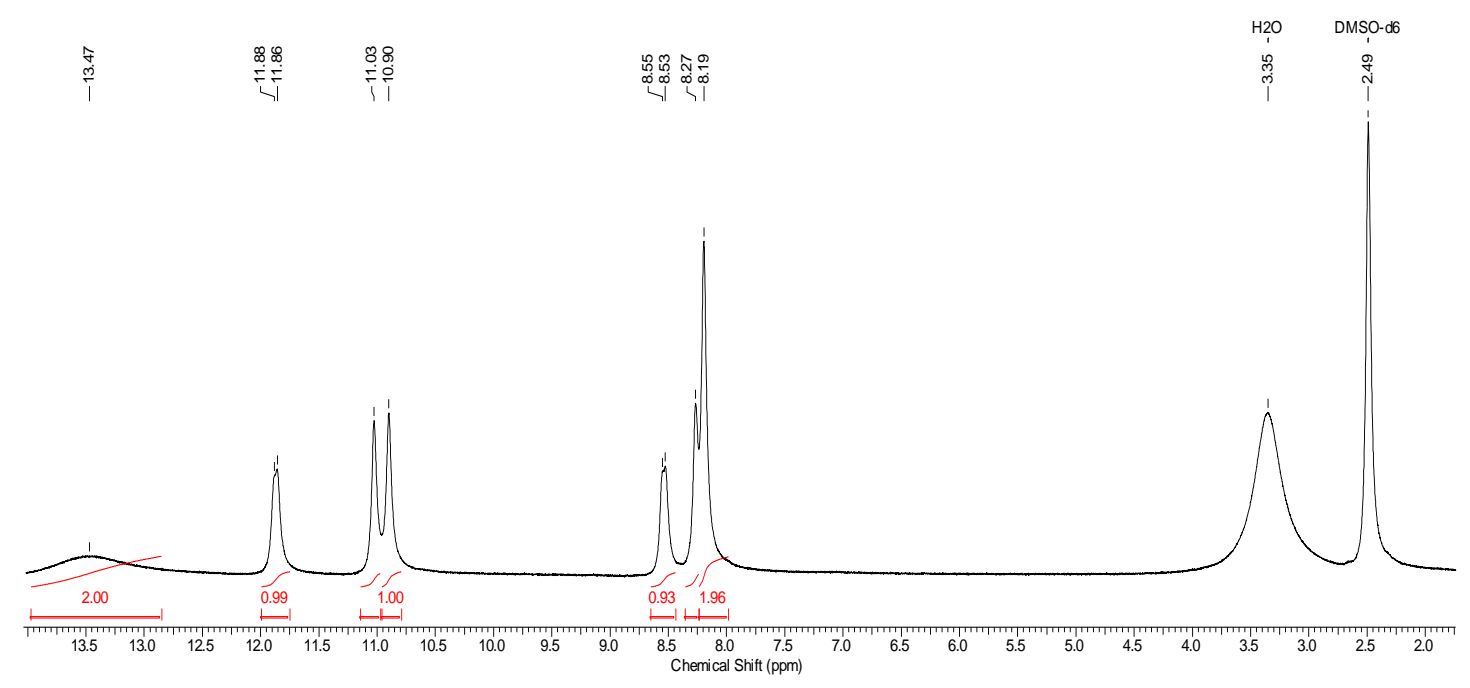

Figure 6. ${ }^{1} \mathrm{H}$ NMR spectra of $\mathbf{2 b}$

The signals at 93.4 and $151.8 \mathrm{ppm}$ belonged to the vinylic carbon atoms of $\mathbf{2} \mathbf{b}$ in the ${ }^{13} \mathrm{C}$ NMR spectra (Figure 7). The four peaks at $150.7,163.6,165.7$ and $166.0 \mathrm{ppm}$ were assigned to the carbonyl carbons of barbiturate moiety and carboxylic acid. Also, the number of observed carbon atom signals in the ${ }^{13} \mathrm{C}$ NMR spectra complies with the expected.

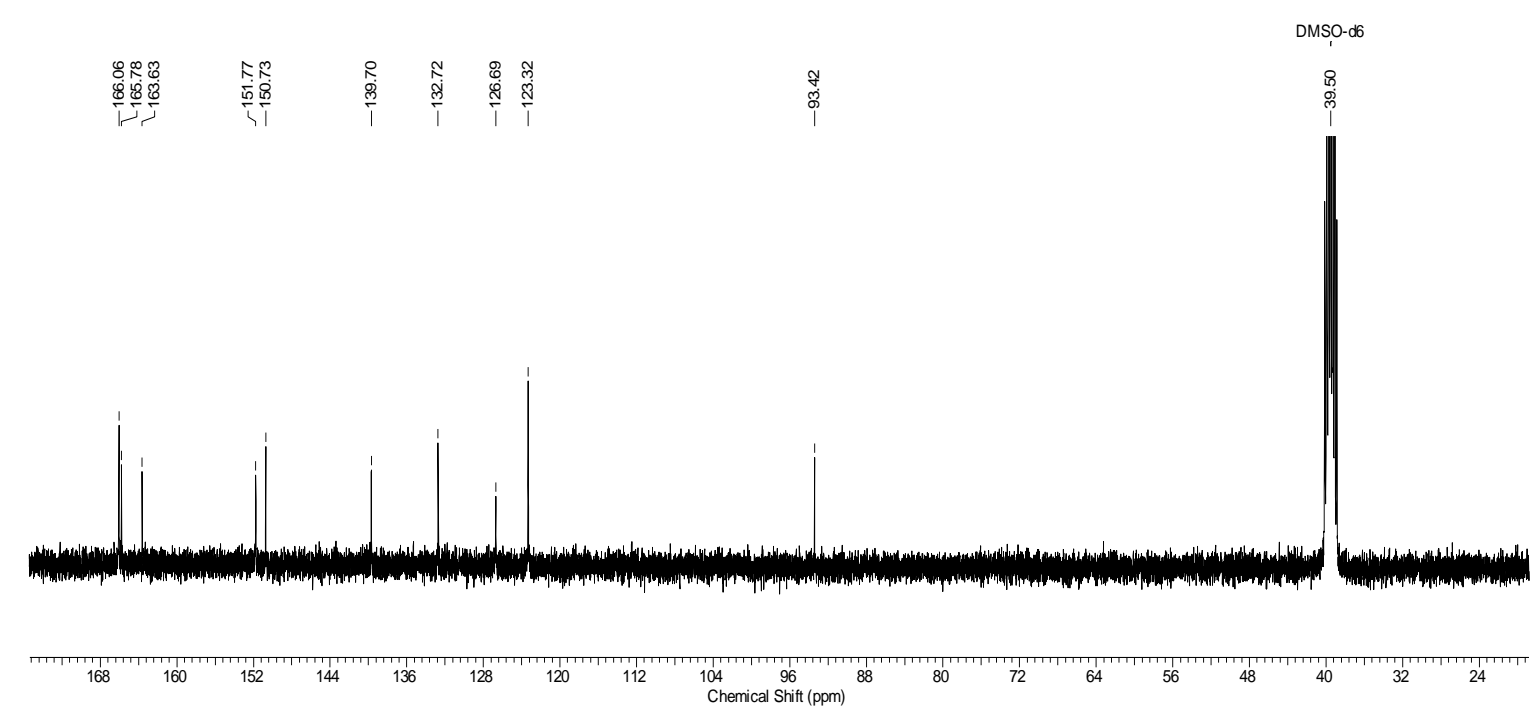

Figure 7. ${ }^{13} \mathrm{C}$ NMR spectra of $\mathbf{2 b}$

In the IR spectra of $\mathbf{2 c}$, the broad absorption bands at 3200-2850 $\mathrm{cm}^{-1}$ were assigned to $v(\mathrm{~N}-\mathrm{H})$ of barbiturate amides and enamine. Also, $v(\mathrm{C}-\mathrm{H})$ absorption bands overlapped in the same region. The strong sharp bands from 1750 to $16500 \mathrm{~cm}^{-1}$ were attributed to $\mathrm{C}=\mathrm{O}$ stretching vibrations. 


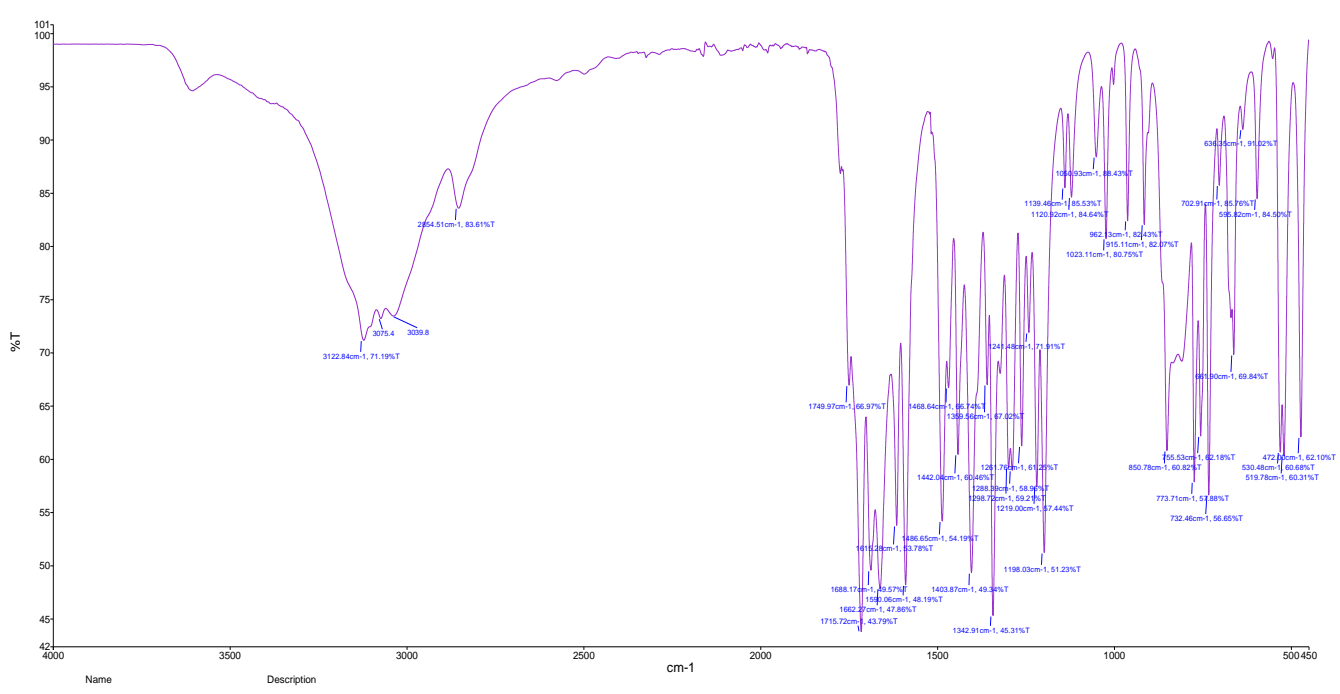

Figure 8. IR spectra of $2 \mathrm{c}$

The ${ }^{1} \mathrm{H}$ NMR spectra of $\mathbf{2 c}$, two singlets at 3.63 and 3.82 ppm belonged para and ortho methoxy protons according to the integration areas of peaks. The singlet peak at $6.86 \mathrm{ppm}$ was assigned to phenyl protons. The $\mathrm{CH}$ and $\mathrm{NH}$ protons of enaminone moiety gave douplet at 8.58 and $11.88 \mathrm{ppm}$, respectively. The $\mathrm{NH}$ protons of barbiturate ring appeared at 10.84 and $10.98 \mathrm{ppm}$ as singlet.

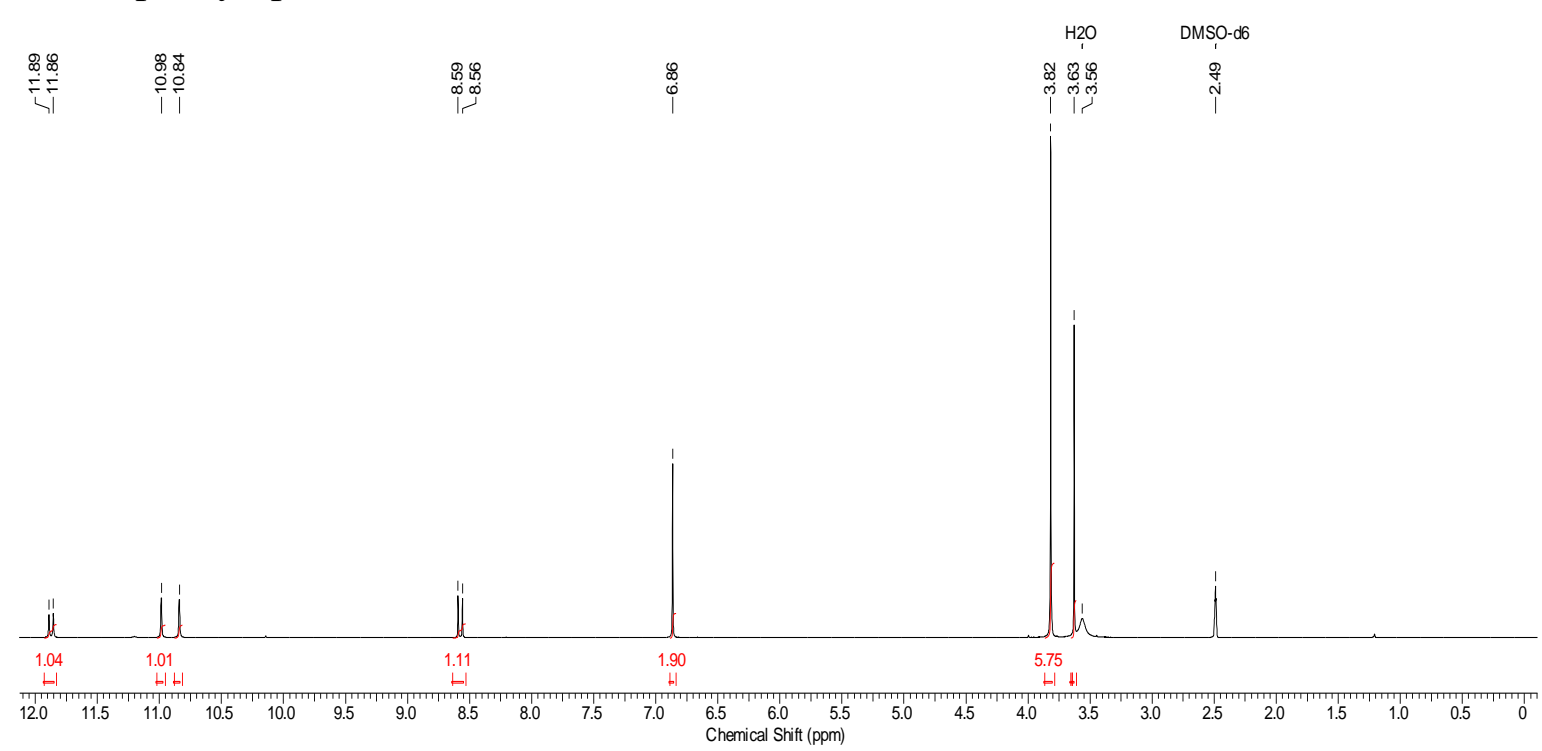

Figure 9. ${ }^{1} \mathrm{H}$ NMR spectra of $\mathbf{2 c}$

The peaks of methoxy carbons appeared at 56.2 and $60.1 \mathrm{ppm}$. The vinylic fragment displayed two signals at 92.2 and $153.6 \mathrm{ppm} \mathbf{2 c}$ in the ${ }^{13} \mathrm{C}$ NMR spectra (Figure 10). The three distinct resonances at 151.6, 163.6 and 166.3 ppm were assigned to the carbonyl carbons of barbiturate moiety. Also, the number of observed carbon atom signals in the ${ }^{13} \mathrm{C}$ NMR spectra is consistent with the expected. 


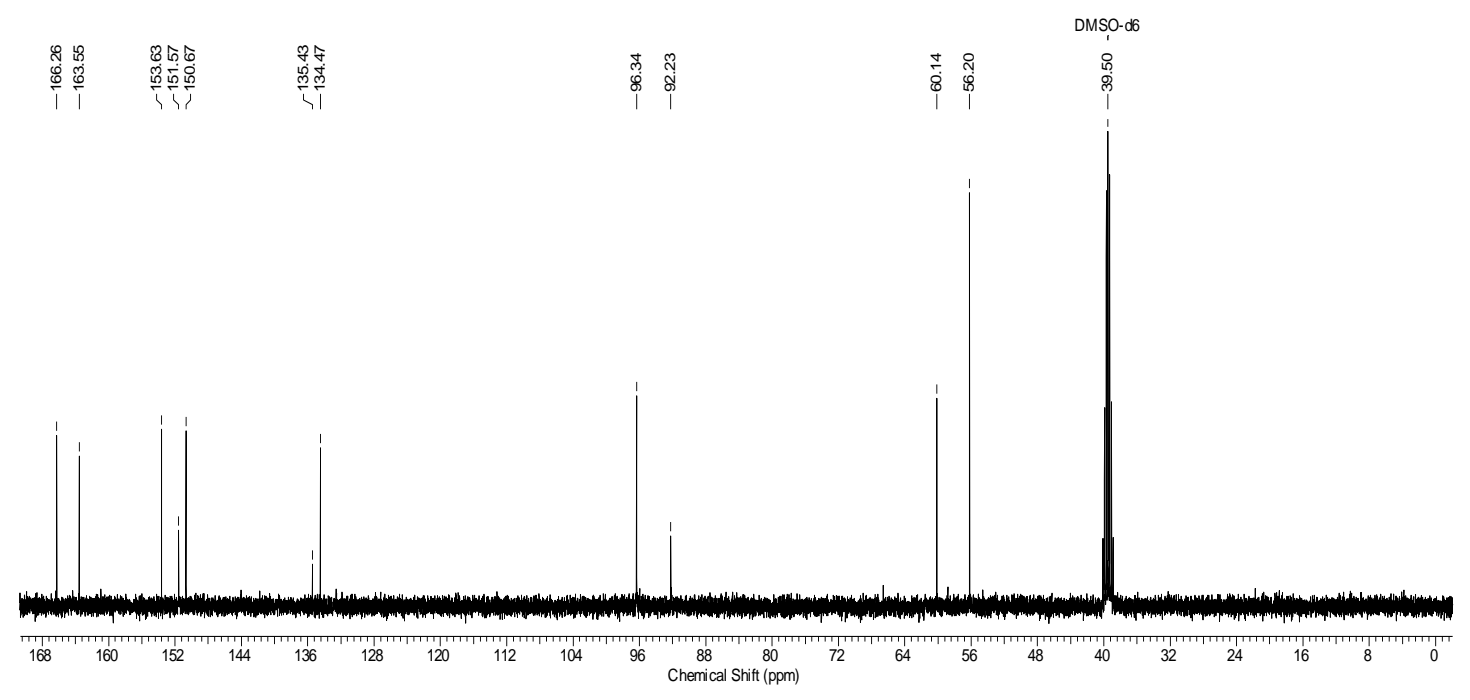

Figure 10. ${ }^{13} \mathrm{C}$ NMR spectra of $\mathbf{2 c}$

The $v(\mathrm{~N}-\mathrm{H})$ and $v(\mathrm{C}-\mathrm{H})$ bands of $\mathbf{2 d}$ appeared at between 2800 and $3260 \mathrm{~cm}^{-1}$. The strong sharp bands from 1720 to $1600 \mathrm{~cm}^{-1}$ were assigned as $\mathrm{C}=\mathrm{O}$ stretching vibrations (Figure 11).

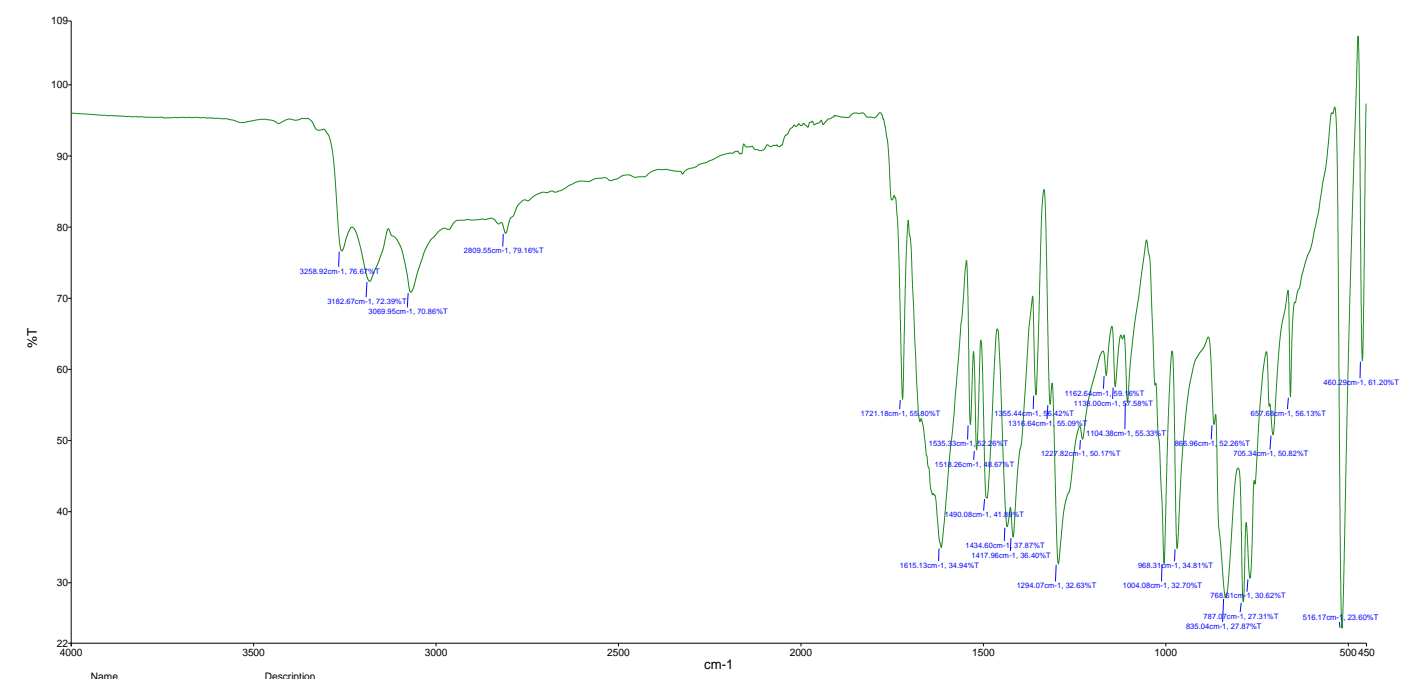

Figure 11. IR spectra of $\mathbf{2 d}$

The ${ }^{1} \mathrm{H}$ NMR spectra of $\mathbf{2 d}$ showed that The $\mathrm{NH}$ and $\mathrm{CH}$ protons of enaminone moiety gave rise to doublet peaks at 8.34 and 11.46 ppm, respectively. The barbiturate amide protons gave two singlet peaks at 10.98 and $11.05 \mathrm{ppm}$. 


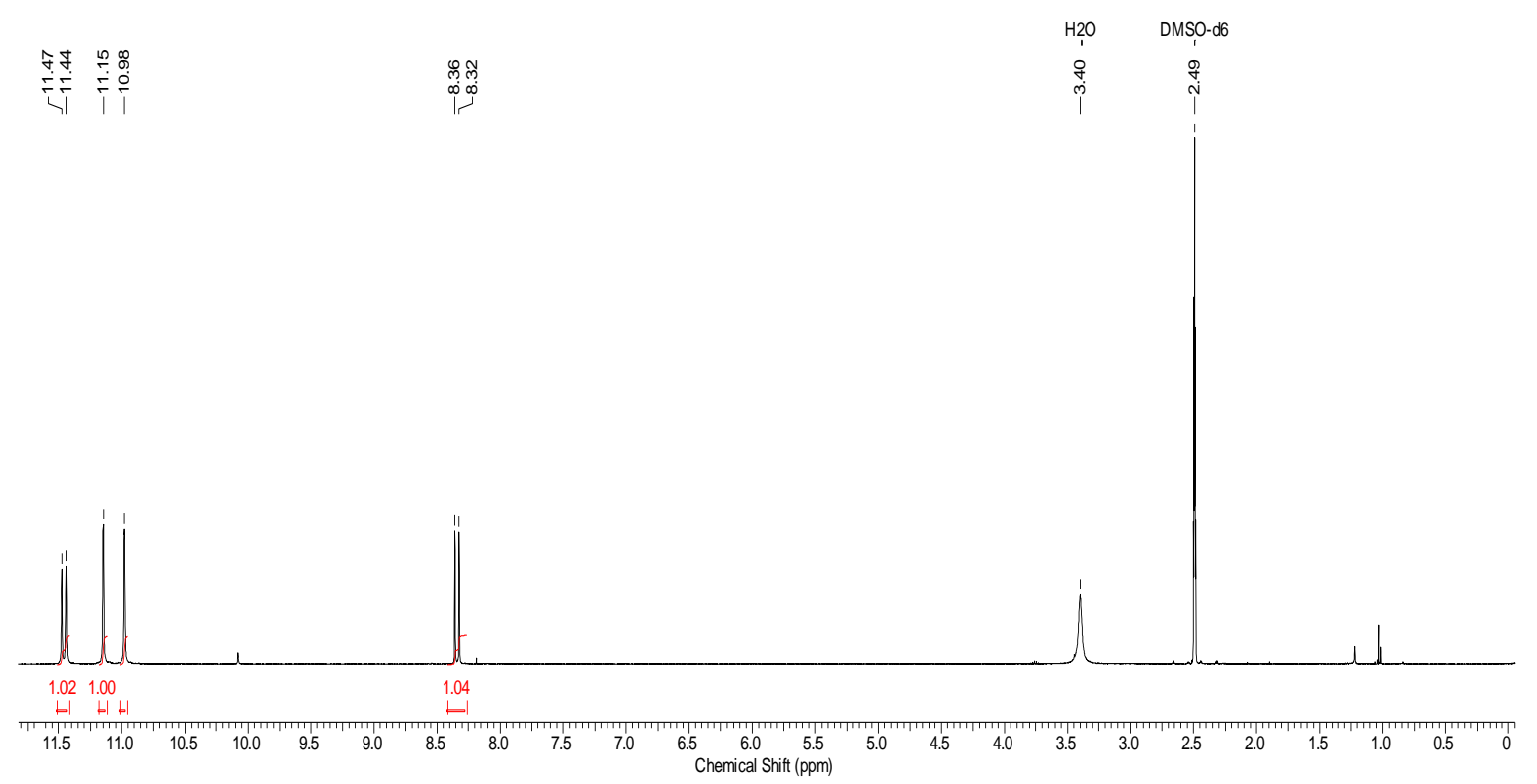

Figure 12. ${ }^{1} \mathrm{H}$ NMR spectra of $\mathbf{2 d}$

The carbons of $\mathrm{C}=\mathrm{C}$ appeared at 94.8 and $155.8 \mathrm{ppm}$ in the ${ }^{13} \mathrm{C}$ NMR spectra of $\mathbf{2 d}$ (Figure 13). The three signals at $150.5,163.1$ and 166.1 ppm were assigned to the carbonyl carbons of

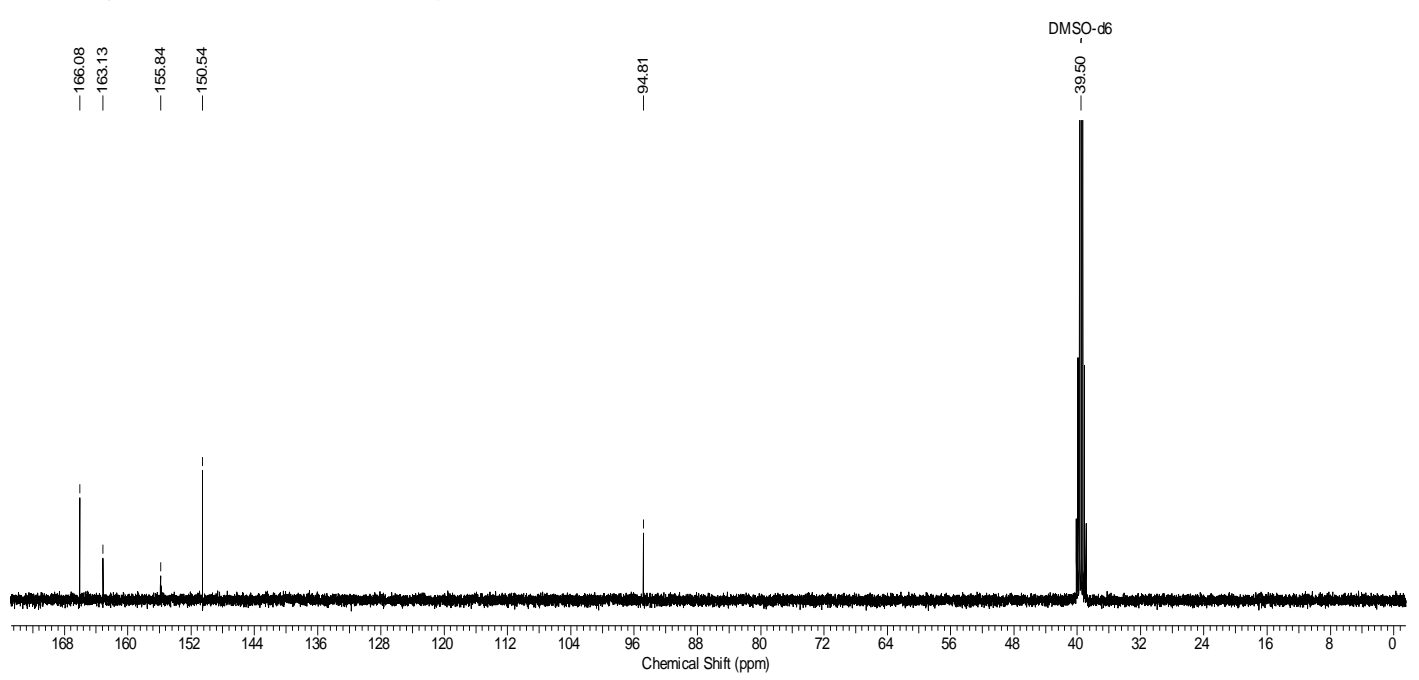

Figure 13. ${ }^{13} \mathrm{C}$ NMR spectra of $\mathbf{2 d}$

On the other hand, the existence of pentafluoride bounded phenyl in $\mathbf{2 d}$ was proved by ${ }^{19} \mathrm{~F}$ NMR spectroscopy. The observed three signals (Figure 14), which were appeared at -167.15, 163.06 and $-155,24 \mathrm{ppm}$, were justified that barbiturate moiety. Unfortunately, fluoride bounded carbon atoms of phenyl could not be detected in the ${ }^{13} \mathrm{C}$ NMR spectra. 


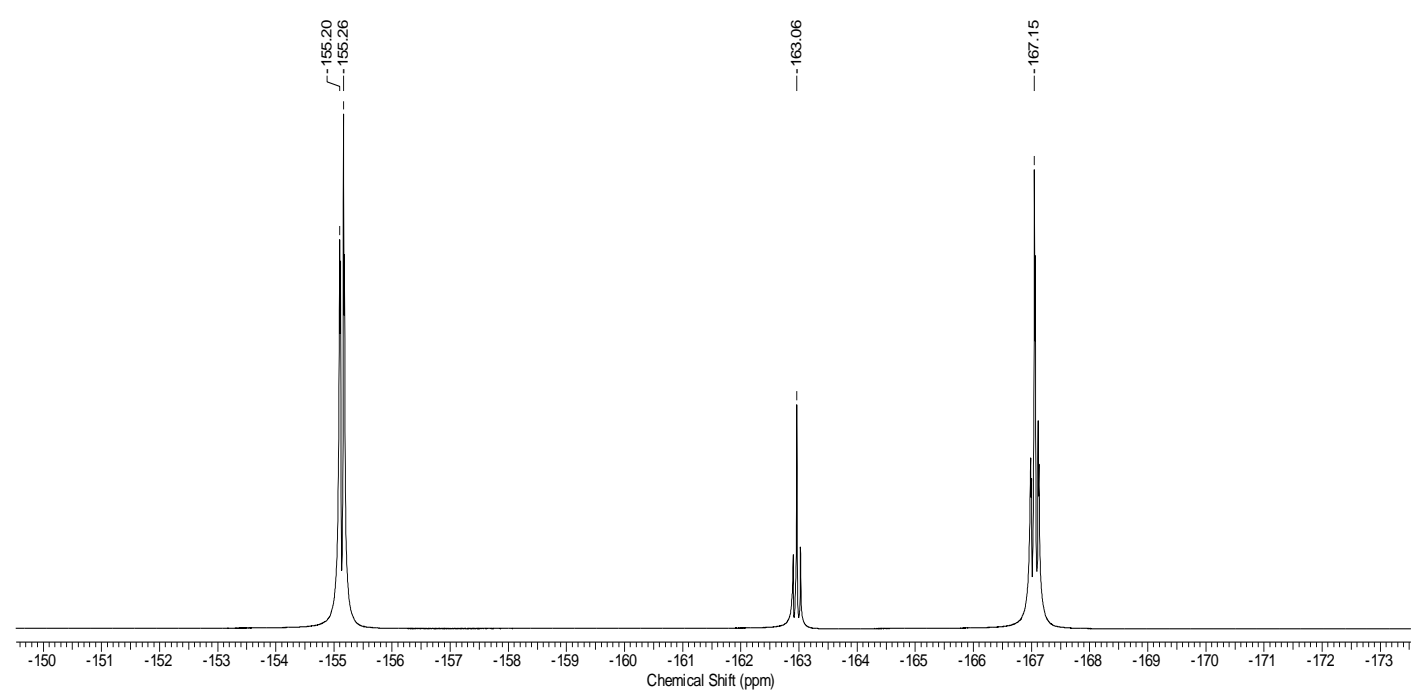

Figure 14. ${ }^{19} \mathrm{~F}$ NMR spectra of $\mathbf{2 d}$

\section{CONCLUSION}

Four enaminones derived from barbituric acid were prepared from the condensation reaction of 5-formyl barbituric acid and selected primer amines with high yield in present study. The structures of the prepared compounds were explained by ATR-FTIR, ${ }^{1} \mathrm{H}$ and ${ }^{13} \mathrm{C}$ NMR spectroscopy. Also, ${ }^{19} \mathrm{~F}$ NMR spectroscopy was used for characterization of $\mathbf{2 d}$. The integration areas of protons in ${ }^{1} \mathrm{H}$ NMR spectra of $\mathbf{2 a - d}$ and the number of the carbon atoms in ${ }^{13} \mathrm{C} \mathrm{NMR}$ spectra of 2a-d cohere with the expected. Also, the obtained data from spectroscopic instruments comply with the previously reported similar enaminones (Neumann et al., 2014; Rauf et al., 2015; Firinc1 et al, 2017). The prepared enaminone derivates can be estimated both versatile ligand for preparation transition metal complexes and synthesis of hetero atom containing organic compounds. The prepared enaminones have potential the being biological active owing to fact that they include barbiturate fragment.

\section{ACKNOWLEDGMENTS}

This work has been supported financially by "Scientific Research Project Unit (BAP) of Aydın Adnan Menderes University" (Project No: FEF-17020).

\section{REFERENCES}

Baldwin GA, Bevan J, Brough D, Ruth Ledder R, Freeman S, 2018. Synthesis and antibacterial activities of enamine derivatives of dehydroacetic acid. Medicinal Chemistry Research, 27: 884889.

Castro-Alvarez A, Carneros H, Costa MA, Vilarrasa J, 2017. Computer-Aided Insight into the Relative Stability of Enamines. Synthesis, 49: 5285-5306.

Kumar P, Zainul O, Laughlin TS, 2018. Inexpensive multigram-scale synthesis of cyclic enamines and 3-N spirocyclopropyl systems. Organic \& Biomolecular Chemistry, 16: 652-656.

Negri G, Kascheres C, Kascheres JA, 2004. Recent Development in Preparation Reactivity and Biological Activity of Enaminoketones and Enaminothiones and Their Utilization to Prepare Heterocyclic Compounds. Journal of Heterocyclic Chemistry, 41: 461- 491.

Elassar AA, El-Khair AA, 2003. Recent developments in the chemistry of enaminones. Tetrahedron, 59: 8463-8480. 
Mahmudov K T, Kopylovich M N, Maharramov A M, Kurbanova M M, Gurbanov A V, Pombeiro A J L, 2014. Barbituric acid as a useful tool for the construction of coordination and supramolecular compounds. Coordination Chemistry Review, 265: 1-37.

Fırınc1 E, Giziroglu E, Celepci D B, Söyleyici H C, Aygün M, 2017. Spiro copper(II)metallacycles derived from 5arylaminomethylene-barbituric acids: Synthesis and structural characterization. Journal of Molecular Structure, 1137: 113118.

Neumann DM, Cammarata A, Backes G, Palmer GE, Jursic B S, 2014. Synthesis and antifungal activity of substituted 2,4,6pyrimidinetrione carbaldehyde hydrazones. Bioorganic \& Medicinal Chemistry, 22: 813-826.
Vidovic D, Findlater M, Cowley HA, 2007. A $\beta$ Diketiminate-Sopported Boron Dication. Journal of American Chemical Society, 129: 8436-8437.

Rauf A, Shahzad S, Bahda M, Yar M, Ahmed F, Hussain N, Akhtar MN, Khan A, Jonczyk J, 2015. Design and synthesis of new barbituric- and thiobarbituric acid derivatives as potent urease inhibitors: Structure activity relationship and molecular modeling studies. Bioorganic \& Medicinal Chemistry, 23: 6049-6058. 